\title{
Exploring Malaysian E-Commerce Taxation: A Qualitative Insight of Online Businesses
}

\author{
Ann Ann Yeo', Tan Chin Lim*2 \& Zubir Azhar ${ }^{3}$ \\ 1, 2,35chool of Management, Universiti Sains Malaysia, Penang, Malaysia \\ 1ann_0714@live.com, ${ }^{* 2}$ tclim@usm.my \& ${ }^{3}$ zubirazhar@usm.my \\ DOI: https://doi.org/10.37134/jcit.vol9.8.2019
}

\begin{abstract}
Electronic commerce (e-commerce) is mushrooming in today's digital world across continents. However, this phenomenon seems not reflective of the tax collected, especially from consumer-to-consumer (C2C) online business transactions. Considering this issue, this paper focuses on the area of C2C business transactions. Our aims are to determine the level of understanding of e-commerce taxation of the students who involved in online businesses during their study years, and to gauge their attitude towards implementation of e-commerce taxation in Malaysia by relating to the existing e-commerce tax rules and regulations. Using an exploratory study approach, a total of six interviews were conducted with students on whether or not their online business income was reported to the tax authority. The results suggested that there was a lack of awareness amongst students concerning the compliance of e-commerce taxation. Factors leading to non-compliance included the perceived low chance of getting caught, the insignificant amount of income being generated, and their current "students" status that camouflaged them from being subject to e-commerce tax. Apparently, they perceived that reporting their online business income to tax authority is troublesome, time wastage and pointless. However, majority of them are willing to report their income after their graduation and ready to join the job market for tax planning purposes. This paper concludes that the non-accounting and accounting students appeared to have different perceptions over the e-commerce taxation due to the level of exposure to taxation. An important practical contribution of this paper concerns the proposal of a series of taxation seminars being conducted to promote compliance and to clarify the misunderstanding that might lead to heavy penalty due to tax evasion.
\end{abstract}

Keywords: E-commerce taxation; C2C; Tax planning; Tax evasion; Permanent establishment; Digital economy

\section{INTRODUCTION}

Tax is the main source of revenue for the government in order to achieve an economic growth and to promote a sound economy. However, the tax collection trend in Malaysia is inconsistent with the country's growing economy and budget deficit (Ullah, 2016). In today's digital world, many people doing online businesses, especially $\mathrm{C} 2 \mathrm{C}$, are without licence or permit to operate the business and earn extra income through online without paying any taxes. The Customs Department of Malaysia's Director, Datuk Seri Subromaniam Tholasy, has pointed out that taxing digital economy can easily generate massive revenues for the country, which currently remains untapped. Besides, he has claimed that the biggest loss in the digital economy appears to be compelling, which involves business-to-consumers (B2C) transactions (Surendra, 2017). It has directly or indirectly imposed a number of challenges to the government administration particularly to the tax system (OECD, 2015).

According to a statement by the Inland Revenue Board of Malaysia (IRB), online businesses run by individuals will be taxed according to the individual income tax rates at a progressive rate of between $0 \%$ and $28 \%$, for sole proprietorship and partnership. Individuals or businesses selling their goods and services on social media must register their businesses with the Companies Commission of Malaysia (CCM), declare their income, and file income 
tax returns. Individual who intends to evade tax is violating the rules and will be subject to heavy penalty between RM1,000 and RM20,000 or imprisonment or both and 300\% of tax undercharged under the provisions Income Tax Act 1967 Section 114(1) (IRB, 2011).

Although doing online business without declaring the income is a violation of the rules, not many people are fully aware of the e-commerce taxation and their knowledge on ecommerce tax seems to be lacking (Mahalingam, 2017). This paper argues that educated people, especially those with accounting background should have knowledge about digital tax. Hence, this study was undertaken to determine the level of understanding of students who involve in online business on e-commerce taxation. Besides that, this study also aims to understand the tax planning of students conducting online businesses as well as their perception towards the fairness of current e-commerce tax rules and regulations. The remainder of the paper will present the problem statement, followed by research objectives, literature review, analysis and findings and lastly discussion and conclusion.

The major influential factors for tax evasion are the probability for detection, compliance behaviour cost and attitudes (perceived fairness) (Alleyne \& Harris, 2016). Individual tax behaviour can be influenced by various factors such as morale attitude, culture, ethical and social norms, religion, education, tax knowledge, income level and gender, political strategies, quality and performance of authorities and tax offices, democracy, corruption and inflation (Noll, Schnell \& Zdravkovic, 2016) Most countries implement self-assessment system on individual taxpayer based on the principles of voluntary tax compliance. In order to collect tax effectively, tax payers must possess adequate tax knowledge and the tax system need not be complex (Saad, 2014). It is a challenge for tax authorities, particularly those in less developed countries like the Philippines and Vietnam, to implement e-commerce tax given that online retailers are skilled in tax avoidance. They have several websites to sell their products and post goods on social media as well as pushing transactions in cash form to circumvent the audit trail. The impact of this new consumer retail market has been felt outside the marketplace and negatively affected state-level sales tax collection. Therefore, a more comprehensive approach has to be taken place to seal the leakage in tax collection. Organisation for Economic Co-operation and Development (OECD) has initiated the tax model for e-commerce and adopted by other countries, including Malaysia. However, the model is more prone to business-to-business (B2B) category especially the cross-border transactions to take advantage of the low tax or tax-free jurisdictions.

The OECD model proposes the action plan based on Base Erosion and Profit Shifting (BEPS) which is designed to ensure that all cross-border businesses are taxed equally and the gaps in international tax rules that allow multinational enterprises to legally but artificially shift profits to low or no-tax jurisdictions are eliminated (OECD 2015). Taking a cue from options analysed in OECD's BEPS Action Plan 1, India proposed an 'equalisation levy' of $6 \%$ withholding tax on 12 digital services in February 2016, imposing on those with non-resident status as they do not have PE in India for the transacted amount exceeding INR100,000 (AviYonah, 2016). Meanwhile, in China, consumers who purchase goods from foreign websites or through a purchasing agent abroad, will be charged according to the postal articles tax scheme which is composed of three different tax rates (i.e. 15\%,30\%, 60\% depending on the types of products). In Malaysia, individual or company who involves in e-commerce activities will be taxed under Income Tax Act 1967. In this regard, the implementation of digital tax will lead to price-hike if service providers decide to pass on the tax by adding it to their existing price. 


\section{PROBLEM STATEMENT}

Many studies have shown that e-commerce would subsequently stir the laws of taxation (Harpaz, 2014). They pointed out the ineffectiveness in collecting tax from e-commerce as the existing tax rules governing transactions was designed for conventional commerce where physical presence or permanent establishment (PE) can be easily identified. Permanent Establishment (PE) is defined as a fixed place of business, in which the business is wholly or partly carried on which includes a place of management, a branch, an office, a factory, a workshop, a mine, oil or gas, quarry or any other place where natural resources are extracted, a building site or construction, installation or assembly project which exists for more than 6 months and a farm or plantation (Choong, 2017).

Digital economy is growing at a remarkable pace due to high penetration of internet and sophisticated electronic devices. Due to its convenience to most users, many online businesses manage to generate high revenue (Bhatnagar, Shukla, \& Singh, 2017). However, the extent literature has argued that many people are conducting online businesses without having proper license or permit to run business but can earn extra income through online means without paying any taxes. This section reviews the literature on awareness of individual especially in students on e-commerce taxation, tax planning as well as perception towards current digital tax rules and regulation to help government overcome the problem of collecting e-commerce taxation revenues.

\section{RESEARCH QUESTIONS}

The research questions designed for this study are:

a) Are students doing online business aware of digital tax?

b) How do they plan their tax?

c) How do they perceive the current rules and regulations of e-commerce taxation?

The above research questions are based on the online business issues that the study attempts to unravel.

\section{PURPOSE OF THE STUDY}

This study concerns whether or not the income derived from online businesses which are engaged by students is reported to the tax authority. Drawing on this concern, this study attempts to achieve the following three-fold objectives:

a) to determine the level of understanding of e-commerce taxation of the students who have been involved in online businesses;

b) to determine students' attitude towards implementation of e-commerce taxation in Malaysia; and

c) to determine students' perception on current e-commerce tax rules and regulations. Such objectives are important in finding the differences between the non-accounting and accounting students engaging themselves in online businesses. 


\section{RESEARCH METHODS}

To achieve the objective of the study, an exploratory research was carried out. This research adopted a qualitative approach in which six students of Universiti Sains Malaysia (USM) who are doing online businesses while pursuing their bachelor of degree were interviewed. A set of semi-structured interview questions was designed to allow respondents to express their perception towards e-commerce taxation. This method also allows the questions to be approached from different angle in order to obtain sufficient information from the respondents. From the in-depth interviews, common themes were compiled based on their responses reflecting experiences and opinions of students on e-commerce taxation. In order to gain a deeper understanding, we considered some observations through the way they express themselves. Besides, journals, literatures, publications and reports were collected to provide secondary information for this study. From the response of the interviewees, 'depth' of information about the answers they have provided are obtained based on the semistructured interview protocol. Further questions were developed based on respondents' responses to the semi-structured questions posed earlier. All interviews were transcribed, and similar responses were grouped together based on certain themes and this followed by our interpretation analysis based on the themes developed before we finally drew a conclusion to the study.

\section{FINDINGS}

\subsection{Awareness of e-commerce taxation among students involving in online business}

In terms of awareness of personal taxation and corporate taxation, the respondents appeared to have a good awareness regarding both. Although the interviewees were students from different courses such as Accounting, Operation Management, Mathematics \& Economics, and Applied Biology, they knew that individuals doing business had to declare their income to Inland Board Revenue (IRB) of Malaysia. Business Owner 1 expressed the following:

"The tax rate imposed will be based on the amount of chargeable income. Individual with more chargeable income will be taxed at a higher rate."

However, Business Owner 5 said:

"The tax rate will be based on the amount of income we earned."

There appeared to be differences in the words used by accounting and non-accounting on the taxable income. While accounting students used a more specific word such as 'chargeable income' to describe the taxable income, non-accounting students used the words 'amount of income we earned'. This was due to the fact that accounting students had had good exposure on taxation in their accounting courses. Thus, they had a better understanding on taxation compared to non-accounting students.

Although all of the interviewees were aware of personal taxation and corporate taxation. Surprisingly, none of them declared their online business income. All accounting students knew they needed to declare such income but for others, they thought that they were not required to declare as this was just a side income from their online business. The reason for 
non-accounting students to decide not to declare their income was based on the point highlighted by some of them that there was no point for them to report their little income to tax authority which would reduce their earnings. For accounting students, they were not willing to declare their income as they did not want to take hassle of registering and reporting their income which were deemed as non-taxable. Business Owner 2 said:

"The income I earned is just a side income from online. I don't think the amount is taxable too. So, why should I trouble myself to register the business and declare the income I earned? Accounting course is so busy, doing such thing just a waste of time, I rather use the time to do my assignments and other important stuff."

On another note, Business Owner 5 stated:

"The income I earned is so little. I don't think there is a point to report to tax authority which will reduce my earnings. I believe there is no one who did part time job during school/ university will report their income."

From here, we can see that non-accounting students misunderstood that they will be taxed if they declare the income. Hence, they refused to declare the income as they want to earn more. For the next question asked, most business owners provided reasons for not reporting their business income to the tax authority. They did mention their income is not fixed as they only provide the service when they are free from those university activities, assignments and exams. Sometimes, they could have zero income for one or two months long. Sometimes, they earned more during semester break. However, they seemed to confuse on how to report the income which were not fixed, and they indicated that it was difficult to calculate. Business Owner 1 expressed her opinion as follows:

"I know. I learned taxation in my second and third years of my degree study. I know I will be getting penalties if I don't report my income. But, I'm still a student. So, I just take it from granted. Besides, in reality, I'm wondering how many of them doing online business are caught? So, why I should trouble myself?"

Business Owner 6 said:

"Are you serious? This one is just a side income, also will be getting penalties? What else I can earn?"

The subsequent question was about the level of awareness of the respondents towards the consequences of not reporting income. Accounting students are aware of the consequences of not reporting tax. They know they will be getting penalties or jailed of not following the rules as they are exposed to the proper procedure and also the consequences during their university's studies, but they have no idea on the exact amount to be fined and the years of jail to be charged of violating the rules. They tend to take it from granted as they are still students. Besides that, in reality, there is failure in penalising those violating the tax rules. For non-accounting students, they are not aware of the penalties of not reporting their online 
business side income. Non-accounting students were also not aware that they enjoyed some benefits by reporting this income. Business Owner 3 said:

"Are you kidding? Reporting income still got benefit? What benefits I can get? What shall I do to get all the benefits?"

From their responses, we can see that students are only aware of the shortcomings of registering their business and declare their income, but they do not aware of the benefits they can get from doing so. For example, for those selling products, they do not know the postage fees and delivery fees of products to customers are tax deductible. For accounting students, they only realised the benefits of doing so after being told. Both would like to understand more on e-commerce taxation and on how to get benefits from registering their business and declaring their income.

\subsection{Tax planning of students involving in online business}

All the interviewees agreed not to declare their income during their undergraduate studies in USM. Majority thought that this was just a side income and the amount is just a few hundred which is less than RM3,000 taxable threshold per month (or RM34,000 per annum). One of the interviewees was wondering how would people doing online business be caught of not reporting their income. Business Owner 2 said:

"I don't think IRB is so free to catch each and every one of them who are doing online business. I will only report if I am lucky enough to be caught by IRB, but I don't think it is so easy to detect as everything is conducted through virtual network."

In making assumption that their business was growing, majority indicated that they would neither declare their income nor register their business. Majority were not willing to make any assumptions that their businesses were growing. They claimed their online businesses were not conducted on a daily basis and their income was not consistent. The reason they did online business was mainly to earn side income given that they were still studying. There was only one interviewee who assumed the possible growth of business. She agreed to register her business provided her business grow to RM5,000 per month. Business Owner 4 said:

"I do not provide service every day. Sometimes when I'm busy with assignments and tutorials, I will not be providing any service. This can be few weeks or even whole month also zero income. So, what is the purpose of registering the business?"

Besides, all of the interviewees expressed the same thought of registering their business as well as declaring such income after they finish their degree. It appears that they are more willing to report their income when they start to do their job full time. As a student, they are not willing to pay taxes, but when they graduate or have the abilities to sustain themselves, they are willing to fulfil the responsibility of being decent citizens to pay taxes. Business Owner 1: 
"I will only pay tax after I graduate. For now, I'm still a student with this (online business) as part time. Moreover, the income is not stable, so how am I going to do tax filing? However, once I started to work full time, I am sure I won't run from taxation."

Business Owner 5 said:

"As a student, I wouldn't willing to pay tax. This is because not every student work as part time or do online business, if I pay, wouldn't it be unfair?"

For accounting student, they indicated the same reason of not reporting their income (i.e. unstable or insignificant income, difficulty in filing for taxation and online business was just a part-time job. For non-accounting students, they regarded paying tax as unfair given that not all students immersed themselves in online business on a part-time basis. When asked about the possibility of planning for tax in the future (i.e. after graduation), majority agreed to prepare a more systematic account and to keep a proper record of each transaction. Business Owner 3 expressed the following:

"Face scrapping service will just be my part time job after I graduate. This will only be done during weekends whenever I have free time. This is just an extra income, I would report my income from permanent job but not this income through online business. I think if I report this income, I will have to do many things, such as providing receipts and keeping all other receipts and bills."

However, an interviewee, who involved in cosmetic business, refused to do so as it was troublesome, and her business only covered a very limited market which she advertised through her social networking. The interviewee decided to remain in what she was then doing.

\subsection{Perception towards current tax rules and regulations}

All the interviewees agreed on the importance to register their business and declare their income to IRB. They knew the use of tax revenue collected to the country. However, Business Owners 1, 2 and 4 thought their abilities as students to help the country were very limited. Business Owner 1 said:

"Even if declare my income, I don't think it makes any difference to government's revenue. So, why shall I trouble myself?"

All of them perceived that the (small) amount of taxes that they needed to pay would not make any difference. They highlighted that even if they declared their income, the income was either non-taxable or charged with very low tax rate. So, the interviewees were not willing to trouble themselves and put themselves into risk of getting less income. Nevertheless, accounting students appeared to be sensitive to the figures. They argued that if they reported their income, there would have to incur additional cost and this would reduce their income further. For example, Business Owner 4 stated: 
"Online business is my source of income during my university life, I work because I need money. If I pay tax, means I have to work harder and consume more time to get the same amount of money. I don't have so much time. I still have to do my assignments as other student."

Business Owners 3, 4, 5 and 6 shared the same thought as they work hard because they need money. If they paid the tax, their income would reduce, and they would have to work harder and longer to get the same amount of money. Clearly, it would be time consuming for students who provided services as compared to those who sold products. They would not do so if their economic abilities were good. For them, their priority was still studying. They just needed to do part-time job to get extra pocket money to have a better life in the university. Business Owner 5 said:

"Not every student works, why should I be treated differently just because of my online business income. Those students who are not working can just get money from their parents. For me, I'm already poor still want me to pay tax?"

Business Owner 5 perceived that it was unfair for students to pay the tax. They argued that those students with sound financial position would not have to go through their path of working and paying the tax. Although all of them thought that it was unfair, they avoided to comment further on this, except one interviewee. She claimed that a certain amount of side income that should be reported shall be set. If the amount of side income exceeded the amount set, then the income should be reported, this would ease their job as part timers, as well as IRB's job. IRB would not have to look on those peanut income declared which are not a taxable amount. With regard to the complexity of the current guidance and procedure on e-commerce taxation, majority of interviewees claimed that the current guidance was not clear and was generally too complex for them to understand. This opinion was shared not only by accounting students but also by non-accounting students. However, they indicated their interest to attend seminars on digital tax to expose them to e-commerce taxation, as well as to maximise the benefit of registering and declaring their income and to prevent them from being penalised for non-compliance, or as Business Owner 6 said:

"Yes. I will register if only the procedure is as easy as $A B C . "$

All of them agreed to register their business as well as declaring their income to IRB if the procedure was clear, simple and easy. Business Owner 5 said:

"I will register if there is someone willing to help me without asking for any charge, If I want to ask anyone to help me do tax filing, there is another charge. So, if anyone is helping me to do all these stuff without any charges, I have no other reason not to do it."

Business Owners 4 and 6 perceived similarly to Business Owner 5. It appeared that they were willing to do things with no charges given that they were still students. 


\section{CONCLUSION}

To this end, this study has emphasised on students' perception on the current e-commerce tax rules and regulations. From the study, we observed that all students who are doing online business in USM are aware of income tax, but they have less understanding on e-commerce taxation and are not really aware of e commerce taxation, students do not plan to report their income during degree and perceived that the current tax rules and regulations are not fair towards students.

There are many reasons driving them not to declare the income. First and foremost, the online business income earned is just a side income and it is unfair for them to be taxed as they are still students. Participants clearly mentioned that their negative perceptions of the income tax system, particularly on the tax to be charged on students who are doing online business. Besides, from their perspective, it is troublesome for them to keep proper documents or records as their priority is still studying. There is also a cost of compliance that will reduce their income. For now, the sales revenues from their clients are $100 \%$ delivered to their hand. However, after declaring their income, there is a probability to be taxed and their income will be reduced. So, they chose not to declare it. We also observed that they find it useless of declaring non-taxable amount. In their opinion, the current guidance and procedure are not clear and complex. They have less knowledge and understanding on e-commerce taxation. Last but not least, failure of system to detect such matter as not much people being caught.

Students tend to only focus on the shortcomings of declaring tax which they will put themselves in risk to be taxed. From here, we can see that the level of understanding of students towards e-commerce taxation is low as they do not know they can get benefits to if they register their business or declare their income. As the business is conducted through online, tax deductible expenses could be postage fees, internet subscription charges and delivery charges. These tax-deductible expenses could reduce their cost. For future tax planning, students will declare their income once they have permanent job and have a bigger amount of salary. However, they refused to declare during degree. They will only change their mind to declare their income during degree provided there is a clearer guidance, a simplified procedure and free platform for learning e-commerce taxation as well as there is a party to help them to do so.

Harpaz (2014) pointed out the ineffectiveness in collecting tax from e-commerce as the existing tax rules governing transactions was designed for conventional commerce where physical presence can be easily identified. This is similar to the findings from this study. The existing tax rules are only for conventional business but when comes to consumer-toconsumer e-commerce, it is very difficult to detect each and every transaction. This makes individuals take it for granted for not declaring their income.

An empirical valuation of a number of determinants of tax evasion which includes probability for detection and compliance behaviour cost was performed by Alleyne \& Harris (2016). This is similar to the study conducted. From financial perspectives, interviewees that are still students are not willing to pay extra using the money they earned to pay tax. From non- financial perspectives, interviewees are still students, the time they used to work is limited, if they are to pay tax, cost incurred, they have to consume more time to work in order to get the same amount of money. As they are still students, they just take it from granted as the probability of being detected is low. Furthermore, the detection rate of non-compliance of 
tax rules and regulations of online business owner is very low. There are less people who do online business being caught from not declaring their income to IRB.

Saad (2014) suggested that tax knowledge is the most influential factor to determine taxpayers' compliance behaviour under the self-assessment system (SAS). Noll, Schnell \& Zdravkovic (2016) also stated that a higher tax knowledge leads to a higher compliance rate. This study is somehow different from the perspective of students. Students have a better knowledge in taxation do not register themselves as taxpayer as well as declare their income to IRB. In this study, a greater knowledge on taxation does not affect the tax compliance of students.

Tax is one of the ways to finance government expenditures and it plays an important role in increasing the government revenue. If taxation system is not effective in collecting tax, many people will use this opportunity to avoid paying tax. As a result, the government cannot allocate revenue for programs and cannot provide desirable social services. Understanding why failure to collect e-commerce taxation revenue happens and knowing factors that cause people not complying the current tax rules and regulation is very important to ensure compliance.

The analysis of this study would be beneficial to both tax literature and practice. In terms of the tax literature, this analysis serves as a guideline for researchers to develop tax complexity measures. Also, the information on possible determinants of non-compliance could be used for future research. From the policy makers' perspectives, this information will assist tax authority to develop their tax education and simplification program. Although $100 \%$ compliance is unlikely, by simplifying compliance, policy makers can at least ensure that actions are taken and create awareness on to peer-to-peer economy that are dominating the digital economy recently.

\section{ACKNOWLEDGMENTS}

The authors would like to express their gratitude and appreciation to School of Management, Universiti Sains Malaysia for providing financial assistance through the school's incentive grant and short-term grant to support this study.

\section{REFERENCES}

Alleyne, P. \& Harris, T. (2016). Antecedents of taxpayers' intentions to engage in tax evasion: evidence from Barbados. Journal of Financial Reporting and Accounting, 15(1), 2-21.

Avi-Yonah, R. S. (2016). Three steps forward, one step back? Reflections on "google taxes" and the destinationbased corporate tax, Nordic Tax Journal, 2016(2), 69-76.

Bhatnagar, P., Shukla, P., \& Singh, S. (2017). Advantages and Challenges of E-commerce. KAAV International Journal of Economics, Commerce \& Business Management, 4(4), 643-646.

Choong, K. F. (2017). Malaysian Taxation: Principles and Practice, 23rd Ed., InfoWorld Publishing.

OECD (2015). Addressing the Tax Challenges of the Digital Economy, Action 1 (2015 Final Report, OECD/G20 Base Erosion and Profit Shifting Project), OECD Publishing, Paris. Available at: http://dx.doi.org/10.1787/9789264241046-en.

Harpaz, J. (2014). Digital Economy Raises Serious Questions for Global Tax Policy. Forbes. https://www.forbes.com/sites/ joeharpaz/2014/03/12/digital-economy-raises-serious-questions-for-global-taxpolicy/\#3d0adc8757ef.

Inland Revenue Board of Malaysia (2011). Offences, Fines and Penalties. Available at: http://www.hasil.gov.my/bt_goindex.php?bt_kump=5\&bt_skum=5\&bt_posi=3\&bt_unit=7000\&bt_sequ=11\&b t_lgv=2. 
Mahalingam, E. (2017). Taxing the digital economy. The Star Online, 19 September 2017. https:/www.thestar.com.my/business/business-news/2017/09/19/taxing-the-digital-economy/.

Noll, J., Schnell, K., \& Zdravkovic, S. (2016). Tax and ethics: A panoramic view (February 9, 2016). Available at SSRN: https://ssrn.com/abstract=2729764 or http://dx.doi.org/10.2139/ssrn.2729764.

OECD (2015a) OECD/G20 Base Erosion and Profit Shifting Project 2015 Final Reports. Executive Summaries. http://www.oecd.org/ctp/beps-reports-2015-executive-summaries.pdf.

Saad, N. (2014). Tax knowledge, tax complexity and tax compliance: Taxpayers' view. Procedia-Social and Behavioral Sciences. 109(1), 1069-1075.

Surendra, E. (2017). Here's how the digital tax will impact online shoppers in Malaysia. iMoney.My, Available at https://www.imoney.my/articles/digital-tax-malaysia.

Ullah, N. (2016). The relationship of government revenue and government expenditure: A case study of Malaysia. Available at https://mpra.ub.uni-muenchen.de/69123/1/MPRA_paper_69123.pdf. 